\title{
Deep drilling on the Faeroe Islands
}

\author{
REgIN WAAGSTEIN, NIELS HALD, OLE JøRGENSEN, PEDER HEDEBOL NIELSEN, ARNE NOE- \\ NYGAARD, JÓANNES RASMUSSEN and GÜNTHER SCHÖNHARTING
}

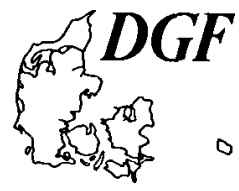

Waagstein, R., Hald, N., Jørgensen, O., Nielsen, P. H., Noe-Nygaard, A., Rasmussen, J. \& Schönhar-
ting, G. : Deep drilling on the Faeroe Islands. Bull. geol. Soc. Denmark, vol. 32 pp. 133-138. Copenha-
gen, September, 4th, 1984. https://doi.org/10.37570/bgsd-1983-32-09

A $2178 \mathrm{~m}$ deep well was drilled in 1981 at Lopra on Suduroy into the oldest and non-exposed parts of the Lower Tertiary Faeroe Island basalt plateau. The drilled sequence consists of thick subaerial lavas and thin tuffaceous sediments and is very similar to the lower part of the exposed sequence. Secondary minerals indicate a fossil temperature of about $200^{\circ} \mathrm{C}$ at the bottom of the well. The present gradient is about $25^{\circ} \mathrm{Cl}$ $\mathrm{km}$. Migrated hydrocarbons suggest the presence of non-volcanogenic sediments at deeper levels.

R. Waagstein, Danmarks Geologiske Undersøgelse, Thoravej 31, DK-2400 København NV, Denmark. N. Hald, O. Jørgensen, A. Noe-Nygaard and G. Schönharting, Geologisk Centralinstitut, Øster Voldgade 10, DK-1350 København K., Denmark. P. H. Nielsen, Danmarks Geologiske Undersøgelse, Far $\emptyset$-afdelingen, Debesartrød, DK-3800 Tórshavn, Faeroe Islands, now at Laboratoriet for Geofysik, Finlandsgade 6-8, DK-8200 Arhus N, Denmark. J. Rasmussen, Føroya Jardfrødisavn, Debesartrød, DK-3800 Tórshavn, Faeroe Islands. August 11th, 1983.

\section{Introduction}

The Faeroe Islands consist of tholeiitic basalt lavas (Noe-Nygaard \& Rasmussen 1968) extruded in the latest Paleocene (Tarling \& Gale 1968, Fitch et al. 1978, Lund 1981) at the time of continental break-up between Europe and Greenland. The exposed volcanic sequence has an aggregate thickness of more than $3 \mathrm{~km}$. It can be divided into three main series, with the oldest series being exposed in two updomed areas in the southern and western part of the islands (Fig. 1a, b) (Rasmussen \& Noe-Nygaard 1969, 1970, Waagstein 1977, Nielsen et al. 1979). The basalt plateau is underlain by continental crust to judge from isotopic (Gariépy et al. 1983, Hald \& Waagstein 1983) and geophysical evidence (Pálmason 1965, Bott et al. 1974, 1976, Casten 1974, Bott 1975).

In 1981 a $2178 \mathrm{~m}$ deep well was drilled into the oldest and non-exposed part of the basalt sequence in order to explore the volcanics, to assess their geothermal prospects and, if possible, to recover part of their substratum. The drill site is located at the village Lopra on Suduroy near the centre of the southern dome. Near the drill site the lavas dip about $3^{\circ}$ to the northeast; they are cut by master joints most of which run southeast with an average spacing of roughly $0.5 \mathrm{~km}$, some being the site of normal faults with displacements of 1 to $30 \mathrm{~m}$. Basaltic dykes form less than $0.5 \%$ of the country rocks; they all strike southeast and most are inclined steeply $\left(85-90^{\circ}\right)$ to the southwest.

The hole was drilled from casing depth (190 m) to the bottom with a $81 / 2^{\prime \prime}$ tri-cone bit using light bentonite mud. Five short cores were recovered from massive flow interiors (Table 1). The bedding in the bore hole is established on the basis of drill cuttings from every second meter using chilled vesicular basalt as a mark of flow tops. The observed transitions between vesicular (amygdaloidal) and massive basalt were later confirmed on the neutron-neutron and the resistivity logs.

\section{Stratigraphy and lithology}

The drilled basalt flows have an average thickness of $20 \mathrm{~m}$, but range in thickness from a few metres to about 50 metres. The flows are mostly simple with massive interiors, thin vesicular bottom zones and several metres thick vesicular top zones. The top zones become aphanitic, scoriaceous and usually also reddish upwards. Some thick 


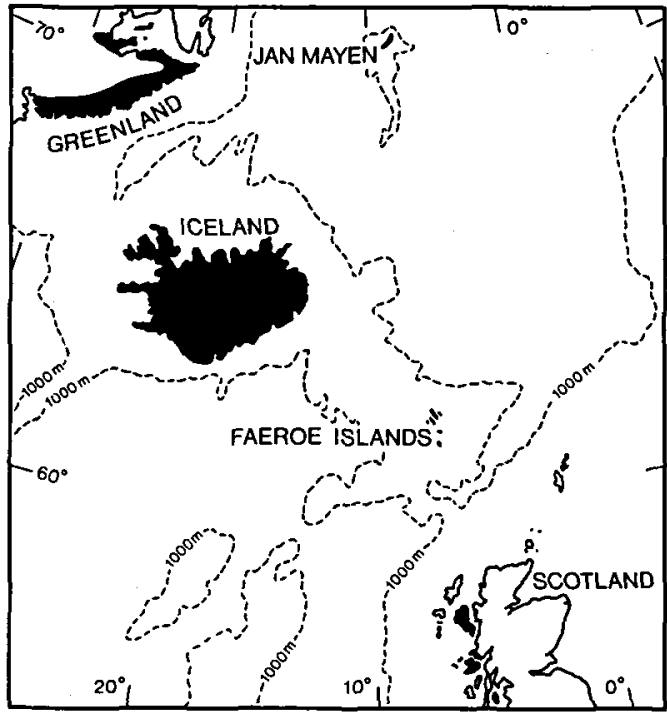

Fig. 1a: Position of the Faeroe Islands. Black: Tertiary to Recent basaltic volcanism.

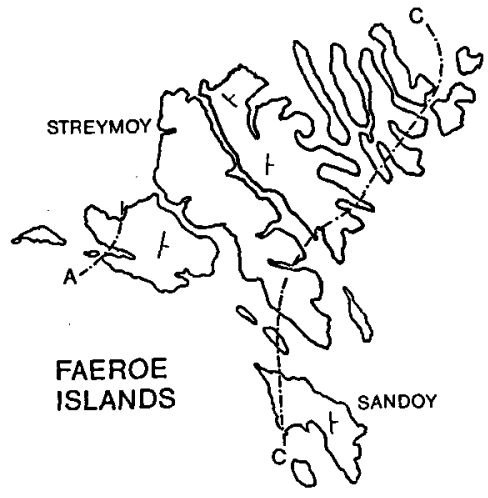

B

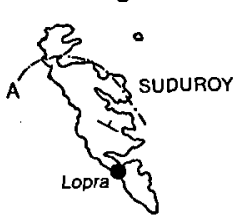

Fig. 1b: The Faeroe Islands. The tholeiitic lava sequence has a combined exposed and drilled thickness of $5 \mathrm{~km}$ and is divided into three main series. The flows in the lower series are sparsely porphyritic with high levels of $\mathrm{Fe}$ and $\mathrm{Ti}$, similar to the main plateau basalts of East Greenland. The flows in the middle and upper series are often strongly plagioclase- or olivine-phyric, and include at higher levels types similar to ocean-ridge basalts as well as rare silicic basalts (Hald \& Waagstein 1983). Thin coal-bearing sediments are present between the lower and middle series (A) and in the uppermost part of the lower series. flows show additional vesicular horizons without recognizable chilling suggesting that they have a compound structure.

The basalts are fine-grained with intergranular texture, and most are sparsely porphyritic in plagioclase, olivine and/or clinopyroxene. The lava interiors are only slightly affected by alteration and even the deepest lavas may contain partly fresh olivine. The cored lavas are $\mathrm{Fe}$ and $\mathrm{Ti}$ rich tholeiites (Table 1, No. 1-5) with $\mathrm{MgO}$ ranging from 4.85 to $7.09 \%$. 41 preliminary trace element analyses of cuttings samples show that the cores are representative of the drilled section.

Fine-grained reddish or brownish tuffaceous sediments are observed on top of about one third of the lava flows in the bore hole, most having an estimated thickness of 0.5 to $2 \mathrm{~m}$ and a few a thickness of 2 to $4 \mathrm{~m}$. They form roughly $2 \%$ of the drilled lava sequence. The sediments mainly consist of clay, sometimes seen to replace small basalt clasts and minerals (probably from the underlying lava top) or glass shards of volcanic ash. Palynological investigations show that the sediments contain very little organic material and only a few palynomorph fragments have been observed (K. Raunsgaard Pedersen, pers. comm.).

The drilled sequence is similar to the exposed lower basalt series in terms of flow thickness, petrography and chemistry (Table 1) and is therefore considered a part of the lower series, which is accordingly at least $3 \mathrm{~km}$ thick. The lavas have all formed subaerially and the oldest strata in the Lopra bore hole must therefore have subsided at least $2.2 \mathrm{~km}$ after their formation. Since the drill site is located on a structural high, this is probably also a minimum figure for the subsidence of the whole Faeroe Islands.

Most of the exposed section in the lower series seems to have formed in a normal polarity earth magnetic field (Fig. 2) (Saxov \& Abrahamsen 1966, Tarling \& Gale 1968, Tarling 1970). The 5 cores from the drilled section show mixed polarities of natural remanent magnetism. However, thermal and AF-cleaning shows that all samples possess a reverse component of remanence. Ore microscopic observations and analysis of rock magnetic properties (to be reported elsewhere) suggest, that this component is primary.

The lower series of the Faeroes show similarities to the reversely magnetized main plateau 
Table 1. Chemical composition of 5 cores from the Lopra bore hole with comparisons

\begin{tabular}{|c|c|c|c|c|c|c|c|c|c|}
\hline \multirow[t]{2}{*}{ Analysis } & \multirow[t]{2}{*}{1} & \multirow[t]{2}{*}{2} & \multirow[t]{2}{*}{3} & \multirow[t]{2}{*}{4} & \multirow[t]{2}{*}{5} & \multicolumn{2}{|c|}{$6^{+}$} & \multicolumn{2}{|c|}{7} \\
\hline & & & & & & $\overline{\mathbf{x}}$ & $\sigma$ & $\overline{\mathbf{x}}$ & $\sigma$ \\
\hline $\mathrm{SiO}_{2}$ & 47.56 & 48.57 & 47.97 & 47.95 & 47.26 & 47.84 & 0.94 & 47.48 & 0.72 \\
\hline $\mathrm{TiO}_{2}$ & 3.41 & 2.66 & 3.02 & 2.88 & 1.77 & 2.70 & 0.54 & 2.51 & 0.40 \\
\hline $\mathrm{Al}_{2} \mathrm{O}_{3}$ & 12.39 & 13.15 & 12.98 & 13.16 & 13.55 & 13.48 & 0.78 & 13.31 & 0.53 \\
\hline $\mathrm{Fe}_{2} \mathrm{O}_{3}$ & 5.68 & 5.68 & 4.92 & 6.53 & 3.88 & 7.04 & 2.08 & 5.09 & 1.08 \\
\hline $\mathrm{FeO}$ & 9.71 & 8.17 & 9.52 & 7.63 & 9.42 & 7.23 & 1.76 & 8.45 & 1.21 \\
\hline $\mathrm{MnO}$ & 0.21 & 0.18 & 0.19 & 0.17 & 0.19 & 0.22 & 0.05 & 0.19 & 0.02 \\
\hline $\mathrm{MgO}$ & 4.85 & 6.38 & 5.74 & 5.58 & 7.09 & 5.80 & 0.65 & 6.37 & 0.48 \\
\hline $\mathrm{CaO}$ & 9.41 & 10.70 & 10.41 & 10.25 & 11.99 & 10.44 & 1.03 & 10.93 & 0.61 \\
\hline $\mathrm{Na}_{2} \mathrm{O}$ & 2.88 & 2.53 & 2.50 & 2.44 & 2.11 & 2.51 & 0.26 & 2.27 & 0.40 \\
\hline $\mathbf{K}_{2} \mathbf{O}$ & 0.93 & 0.28 & 0.21 & 0.65 & 0.21 & 0.42 & 0.17 & 0.26 & 0.12 \\
\hline $\mathrm{P}_{2} \mathrm{O}_{5}$ & 0.39 & 0.21 & 0.26 & 0.26 & 0.14 & 0.29 & 0.08 & 0.27 & 0.05 \\
\hline L.O.I. & 2.53 & 2.32 & 2.80 & 2.60 & 2.99 & 2.04 & 0.62 & 2.25 & 0.87 \\
\hline Total & 99.95 & 100.83 & 100.52 & 100.10 & 100.60 & 100.01 & & 99.38 & \\
\hline $\mathrm{FeO} * / \mathrm{MgO}$ & 3.06 & 2.08 & 2.43 & 2.42 & 1.82 & 2.34 & 0.37 & 2.05 & 0.27 \\
\hline \multicolumn{10}{|c|}{ Trace elements, in ppm. } \\
\hline $\mathrm{Sc}$ & 34 & 41 & 44 & 44 & 46 & & & & \\
\hline $\mathrm{V}$ & 404 & 345 & 403 & 381 & 330 & 388 & 73 & 338 & 23 \\
\hline $\mathrm{Cr}$ & 59 & 113 & 50 & 72 & 148 & 120 & 54 & 148 & 65 \\
\hline Co & 62 & 71 & 66 & 58 & 64 & 53 & 9 & 47 & 3 \\
\hline $\mathrm{Ni}$ & 46 & 73 & 55 & 56 & 91 & 89 & 23 & 78 & 25 \\
\hline $\mathrm{Zn}$ & 124 & 119 & 113 & 119 & 79 & & & & \\
\hline Rb & 16 & 1 & 1 & 7 & 3. & & & 24 & 22 \\
\hline $\mathrm{Sr}$ & 290 & 242 & 261 & 269 & 179 & 276 & 81 & 289 & 59 \\
\hline $\mathbf{Y}$ & 41 & 32 & 34 & 31 & 29 & & & 32 & 5 \\
\hline $\mathrm{Zr}$ & 264 & 142 & 162 & 159 & 86 & 211 & 58 & 153 & 34 \\
\hline $\mathrm{Nb}$ & 25 & 8 & 12 & 10 & 4 & & & 10 & 4 \\
\hline $\mathrm{Ba}$ & 239 & 99 & 122 & 118 & 102 & 100 & 41 & 69 & 38 \\
\hline $\mathrm{Ce}$ & 72 & 39 & 47 & 43 & 19 & & & & \\
\hline $\mathrm{Nd}$ & 50 & 29 & 33 & 32 & 22 & & & & \\
\hline
\end{tabular}

(1) Core 1, 337.5 m (depth below kelly bushing $11.5 \mathrm{~m}$ above sea level); (2) Core 2, $861.7 \mathrm{~m}$; (3) Core 3, 1218.5 m; (4) Core 4, 1922.9 $\mathrm{m} ;(5)$ Core 5, $2177.3 \mathrm{~m}$; (6) Average composition of 35 lavas from the exposed part of the lower series, Faeroe Islands; (7) Average composition of 23 lavas from the Plateau Basalts, East Greenland (computed from Brooks et al. 1976). (1) - (5): XRF by G. Hornung, University of Leeds; (6) major elements: XRF or wet chemistry by Ib Sørensen, Geological Survey of Greenland; (6) trace elements: emission spectrography by $\mathbf{H}$. Bollingberg, University of Copenhagen.

+The complete analytical data may be obtained from $R$. W. on request.

basalt series in East Greenland (Brooks et al. 1976). We here tentatively suggest that the lower series - except for the upper $700 \mathrm{~m}$ - has formed within the same long reverse magnetic period as the East Greenland basalts (Hailwood et al. 1973, Nielsen et al. 1981). This period has been correlated in East Greenland with sea-floor anomaly 24-25 (Soper et al. 1976). If both these correlations are correct the reversely magnetized middle and upper basalt series of the Faeroes are younger than the main East Greenland basalts and must have formed after the onset of sea floor spreading between Greenland and the FaeroeRockall Plateau (Soper et al. 1976). This may explain why MORB type basalts become increasingly abundant upwards in the middle and upper series of the Faeroes (Fig. 1b) (Schilling \& Noe-Nygaard 1974, Bollingberg et al. 1975), but are rare in the East Greenland lava succession (Brooks \& Nielsen 1982).

\section{Metamorphic Zonation}

The sequence in the Lopra well has been affected by thermal metamorphism during burial, and the vesicular flow tops are filled with zeolites and other low-temperature minerals showing a systematic distribution with depth (Fig. 2). This metamorphic zonation is very similar to that in low-temperature geothermal areas in Iceland but different from the zonation in the active rift of Iceland (Kristmannsdóttir \& Tómasson 1978, Kristmannsdóttir 1982). Chabazite is only found at levels above the bore hole (Fig. 2); it is unstable above a temperature of roughly $70^{\circ} \mathrm{C}$ 


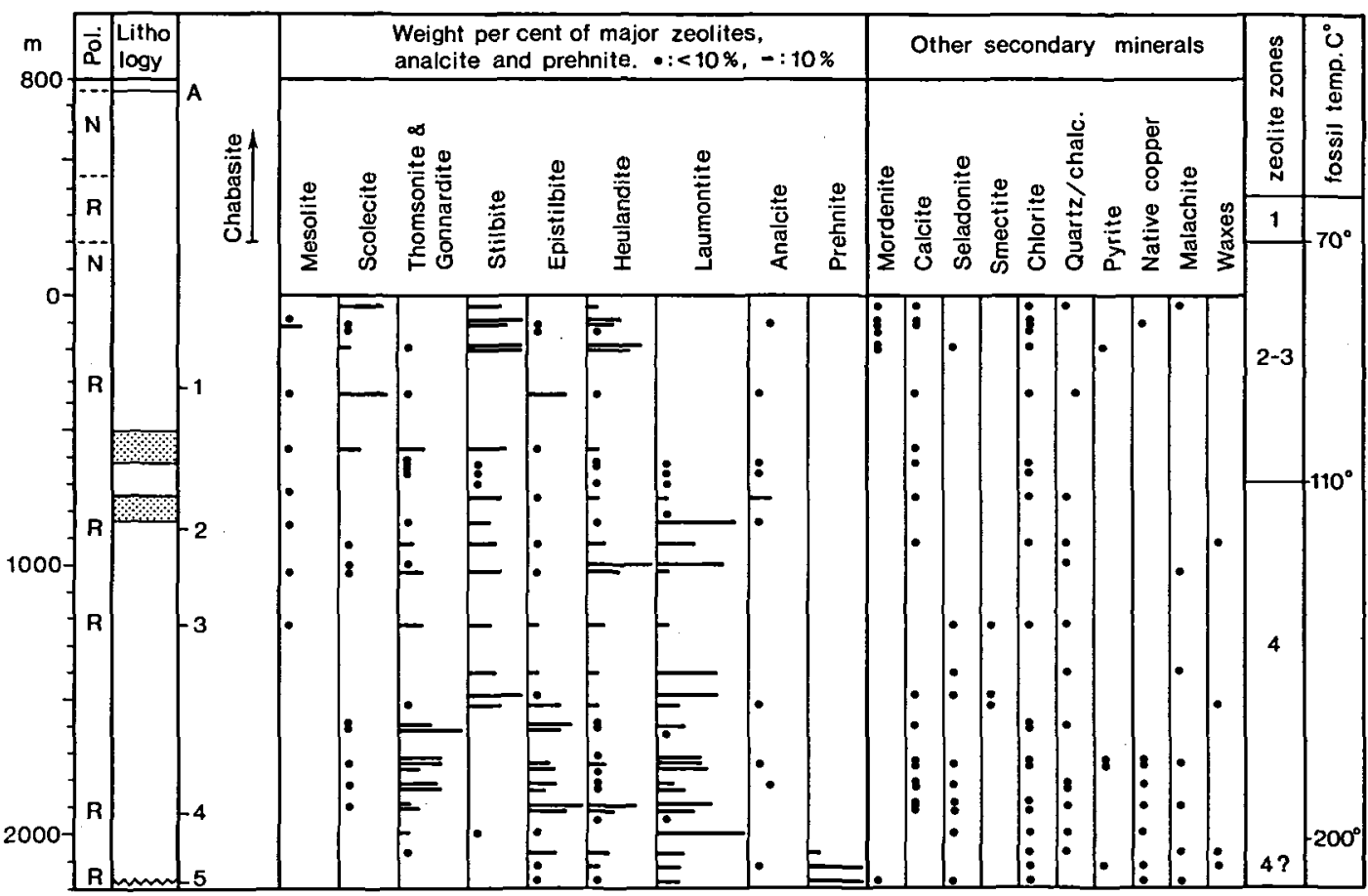

Fig. 2. Profiles through the lower basalt series, Faeroe Islands. Metre scale: Vertical depth below or stratigraphic height above the top of the Lopra well $(12 \mathrm{~m}$ asl). Pol.: primary magnetic polarity of exposed and cored lavas $(\mathrm{N}=$ normal, $\mathrm{R}=$ reverse). Lithology: $A=$ coal-bearing sequence on top of the lower series; 1 to 5 = cores; blank = lavas and thin interlayered tuffaceous sediments; dotted = fine-grained dolerite intrusions (near-vertical dykes?). Secondary minerals: weight per cent of major zeolites, analcite and prehnite sorted visually from a portion of 50-300 cuttings of secondary minerals (left); presence of other secondary minerals (right). Zeolite zones from Kristmannsdóttir \& Tómasson 1978. Fossil temperatures: see text. The secondary minerals have been identified by optical and XRD methods.

(Kristmannsdóttir \& Tómasson 1978). Laumontite appears at $700 \mathrm{~m}$ in the bore hole and has probably formed at temperatures above $110^{\circ} \mathrm{C}$ (Liou 1971a, Kristmannsdóttir \& Tómasson 1978). Prehnite is common below $2100 \mathrm{~m}$ in the Lopra well but uncommon in Icelandic wells where it makes its first appearance at the same or a slightly smaller depth than epidote, wairakite and pumpellyite (Kristmannsdóttir \& Tómasson 1978, Mehegan et al. 1982, Viereck et al. 1982). The latter minerals are not observed in the Lopra well, but combining the field and experimental data for all four minerals we estimate a minimum temperature of formation for the prehnite of roughly $200^{\circ} \mathrm{C}$ (Liou $1971 \mathrm{~b}$, Turner 1981). From the first appearence of laumontite and prehnite we deduce a fossil geothermal gradient of $50-80^{\circ} \mathrm{C} / \mathrm{km}$ similar to or lower than the fossil gradient of low temperature areas in Iceland (Kristmannsdóttir 1982). The present gradient (March 1983) in the Lopra well is about $25^{\circ} \mathrm{C} / \mathrm{km}$.
A linear extrapolation of the fossil gradient at Lopra places the original top of the basalt plateau at less than $1 \mathrm{~km}$ above the lower series. This suggests a considerable thinning of the two younger series in the southern part of the Faeroes and is in accordance with fission track datings of zeolites (Koul et al. 1981).

\section{Migrated hydrocarbons}

In 4 cuttings samples from between 900 and 2100 $m$ depth in the Lopra well a waxy, inflammable substance has been found as a thin coating on the late formed minerals (gonnardite, scolecite, heulandite and calcite). Similar coatings have been found on chabazite in exposures elsewhere on the islands and the wax has therefore probably been deposited at temperatures of less than $70^{\circ} \mathrm{C}$. Preliminary pyrolysis investigations suggest that 
the wax is a migrated bitumineous substance with a relatively high content of hydrogen.

When the well was reopened in March 1983, the casing was gas-filled. Analyses made at Ris $\emptyset$ National Laboratory show that the gas consists of $71.1 \% \mathrm{CH}_{4}, 0.43 \% \mathrm{C}_{2} \mathrm{H}_{6}, 0.09 \% \mathrm{C}_{3} \mathrm{H}_{8}, 0.04 \%$ $\mathrm{C}_{n} \mathrm{H}_{\mathrm{x}}, 28.0 \% \mathrm{~N}_{2}, 0.23 \% \mathrm{O}_{2}, 0.025 \%$ Ar and $0.1 \%$ $\mathrm{CO}_{2}$. The production rate of the gas is about 1 cubic metre per day. The emanation of gas was negligible during drilling, probably because of the additional weight of the drilling mud.

The methane-rich gas and the wax coatings probably have a common organic source though the analyses at hand do not present any direct clues to the type of the organic matter of the source. The only known possible source rocks are the thin coal beds between the lower and middle series and in the uppermost part of the lower series (Rasmussen \& Noe-Nygaard 1969, 1970). However, these beds are an unlikely source of the hydrocarbons in the well because they occur at a much higher stratigraphic level. The hydrocarbons in the Lopra well may thus provide the first evidence of non-volcanogenic sediments below or within the deepest part of the basalt plateau.

Acknowledgements. The drilling was organized by the government of the Faeroe Islands with partial financial support from the Carlsberg Foundation. The Icelandic National Energy Authority carried out the drilling and the wire-line logging.

\section{Dansk sammendrag}

Færøerne består af tholeiitiske plateaubasalter med en samlet, blottet mægtighed på mere end $3 \mathrm{~km}$. Basalterne er kommet til udbrud $i \emptyset v r e$ palæocæn samtidig med dannelsen af de østgrønlandske basalter og samtidig med den endelige adskillelse af Grønland og Europa. Geofysiske undersøgelser tyder på, at de færøske basalter hviler pà et kontinentalt underlag, hvilket bekræftes af basalternes indhold af radiogene isotoper. I 1981 gennemførte det færøske landsstyre en $2178 \mathrm{~m}$ dyb boring på Suduroy i den aldste, ublottede del af lavaserien. Udover at skaffe viden om disse lavaer og - om muligt - de prævulkanske bjergarter skulle boringen skabe grundlag for en vurdering af det geotermiske potentiel. Den gennemborede lagserie består af tykke, tholeiitiske lavaer vekslende med tynde tuflag og viser stor lighed med de nederste $900 \mathrm{~m}$ af den blottede lagserie. Lavaeme er dannet på Jand. Der er således siden palæocan sket en betydelig nedsynkning, som formodentlig har omfattet hele den færøske øgruppe. Sekundære mineraler, dannet ved termal metamorfose, viser, at temperaturen i de nederste gennemborede lag har været ca. $200^{\circ} \mathrm{C}$, med en termisk gradient på $50-80^{\circ} \mathrm{C} / \mathrm{km}$. Den nuværende gradient er $25^{\circ} \mathrm{C} / \mathrm{km}$. I marts 1983 konstateredes det, at den $\emptyset$ verste, forede del af borehullet var gasfyldt ( $71 \%$ methan og $28 \%$ kvælstof). Efter aflastning af trykket har gasudstrømningen været ca. $1 \mathrm{~m}^{3}$ om dagen. Kulbrinter er desuden fundet som tynde belægninger (jordvoks) på de sekundære mineraler. Forekomsten af kulbrinter $i$ boringen tyder på tilstedeværelsen af sedimenter med organisk indhold på dybere niveau.

\section{References}

Bollingberg, H., Brooks, C. K., and Noe-Nygaard, A. 1975: Trace element variations in Faeroese basalts and their possible relationships to ocean floor spreading history. Bull. geol. Soc. Denmark, 24, 55-60.

Bott, M. H. P. 1975: Structure and evolution of the north Scottish shelf, the Faeroe block and the intervening region. In: Woodland, A. W. (Ed.): Petroleum and the continental shelf of North West Europe, Vol. 1, Geology, 105-113. Applied Science Publ., Barking.

Bott, M. H. P., Sunderland, J., Smith, P. J., Casten, U. and Saxov, S. 1974: Evidence for continental crust beneath the Faeroe Islands. Nature, 248, 202-204.

Bott, M. H. P., Nielsen, P. H. and Sunderland, J. 1976: Converted $\mathbf{P}$-waves originating at the continental margin between the Iceland-Faeroe Ridge and the Faeroe block. Geophys. J. R. astr. Soc., 44, 229-238.

Brooks, C. K. and Nielsen, T. F. D. 1982: The Phanerozoic development of the Kangerdlugssuaq area, East Greenland. Meddr Gronland, Geosci., 9, 30 p.

Brooks, C. K., Nielsen, T. F. D. and Petersen, T. S. 1976: The Blosseville coast basalts of East Greenland: their occurrence, composition and temporal variations. Contr. Miner. Petrol., 58, 279-292.

Casten, U. 1974: Eine Analyse seismischer Registrierungen von den Färöer Inseln. Hamburger Geophysikalische Einzelschriften 21, Geophysikalische Institute der Universität Hamburg.

Fitch, F. J., Hooker, P. J., Miller, J. A. and Brereton, N. R. 1978: Glauconite dating of Palaeocene-Eocene rocks from East Kent and the time-scale of Palaeogene volcanism in the North Atlantic region. J. geol. Soc. Lond., 135, 499512.

Gariépy, C., Ludden, J. and Brooks, C. 1983: Isotopic and trace element constraints on the genesis of the Faeroe lava pile. Earth planet. Sci. Lett., 63, 257-272.

Hailwood, E. A., Tarling, D. H., Mitchell, J. G. and Løvlie, R. 1973: Preliminary observations on the palaeomagnetism and radiometric ages of the Tertiary basalt sequence of Scoresby Sund, East Greenland. Rapp. Grønlands geol. Unders., 58, 43-47.

Hald, N. and Waagstein, R. 1983: Silicic basalts from the Faeroe Islands: Evidence of crustal contamination. In: Bott, M. H. P., Saxov, S., Talwani, M. and Thiede, J. (Eds.): Structure and development of the Greenland-Scotland Ridge, 343-349. Plenum Press, New York/London.

Koul, S. L., Chadderton, L. T. and Brooks, C. K. 1981: Fission track dating of zeolites. Nature, 294, 347-350.

Kristmannsdóttir, H. 1982: Alteration in the IRDP drill core compared with other drill holes in Iceland. J. geophys. Res. $87,6525-6531$.

Kristmannsdóttir, H. and Tómasson, J. 1978: Zeolite zones in geothermal areas in Iceland. In: Sand, L. B. and Mumpton, F. M. (Eds.): Natural zeolites, occurrences, properties, use, 277-284. Pergamon, New York.

Liou, J. G. 1971a: Stilbite-laumontite equilibrium. Contr. Miner. Petrol., 31, 171-177.

Liou, J. G. 1971b: Synthesis and stability relations of prehnite, $\mathrm{Ca}_{3} \mathrm{Al}_{2} \mathrm{Si}_{3} \mathrm{O}_{10}(\mathrm{OH})_{2}$. Am. Miner., 56, 507-531.

Lund, J. 1981: Eine Ober-Paläozäne Mikroflora von den Färöern, Dänemark. Cour. Forsch.-Inst. Senckenberg, 50, 41-45. Reprinted in: Bott, M. H. P., Saxov, S., Talwani, M. and Thiede, 'J. (Eds.): Structure and development of the Greenland-Scotland Ridge, 417-423. Plenum Press, New York. 
Mehegan, J. M., Robinson, P. T. and Delaney, J. R. 1982: Secondary mineralization and hydrothermal alteration in the Reydarfjordur drill core, Eastern Iceland. J. geophys. Res., 87, 6511-6524.

Nielsen, P. H., Waagstein, R., Rasmussen, J. and Larsen, B. 1979: Marine seismic investigation of the shelf around the Faeroe Islands. Fródskaparrit, 27, 102-112. Reprinted in: Danm. geol. Unders. Árbog 1981, 101-109 (1982).

Nielsen, T. F. D., Soper, N. J., Brooks, C. K., Faller, A. M., Higgins, A. C. and Matthews, D. W. 1981: The pre-basaltic sediments and the Lower Basalts at Kangerdlugssuaq, East Greenland: their stratigraphy, lithology, palaeomagnetism and petrology. Meddr Grønland, Geosci., 6, 28 p.

Noe-Nygaard, A. and Rasmussen J. 1968: Petrology of a 3000 metre sequence of basaltic lavas in the Faeroe Islands Lithos, 1, 286-304.

Pálmason, G. 1965: Seismic refraction measurements of the basalt lavas of the Faeroe Islands. Tectonophysics, 2, 475482.

Rasmussen, J, and Noe-Nygaard, A. 1969: Beskrivelse til geologisk kort over Færøerne. Danm. geol. Unders., 1 series, No, 24, 370 p.

Rasmussen, J, and Noe-Nygaard, A. 1970: Geology of the Faeroe Islands. Danm. geol. Unders., 1 series, No. 25, $142 \mathrm{p}$.
Saxov, S. and Abrahamsen, N. 1966: Some geophysical investigations in the Faroe Islands, a preliminary report. $Z$. Geophys. Sonderheft, 32, 455-471.

Schilling, J.-G. and Noe-Nygaard, A. 1974: Faeroe-Iceland plume: rare-earth evidence. Earth planet. Sci. Lett., 24, $1-14$.

Soper, N. J., Downie, C., Higgins, A. C. and Costa, L. I. 1976: Biostratigraphic ages of Tertiary basalts on the East Greenland continental margin and their relationship to plate separation in the Northeast Atlantic. Earth planet. Sci. Lett., 32, 149-157.

Tarling, D. H. 1970: Palaeomagnetic results from the Faeroe Islands. In: Runcorn, K. (Ed.): Palaeogeophysics, 193208. Acad. Press, London/New York.

Tarling, D. H. and Gale, N. H. 1968: Isotopic dating and palaeomagnetic polarity in the Faeroe Islands. Nature, 218, 1043-1044.

Turner, F. J. 1981: Metamorphic rocks, 524 p., McGraw-Hill, New York.

Viereck, L. G., Griffin, B. J., Schmincke, H.-U. and Pritchard, R. G. 1982: Volcaniclastic rocks of the Reydarfjordur drill hole, Eastern Iceland. 2, alteration. J. geophys. Res., 87, 6459-6476.

Waagstein, R. 1977: The geology of the Faeroe Plateau. Unpubl. thesis, Univ. of Copenhagen, 183 p. 